\title{
Adequacy of the accelerated aging test for soybean seeds
}

Anna dos Santos Suñé, Andréia da Silva Almeida, Josiane Cantuária Figueiredo, Bruna Barreto dos Reis, Camila de Avila Nunes, Carem Rosane Coutinho Saraiva, Lais Kroessin, William Lorenski Correa, Lilian Vanussa Madruga de Tunes

Universidade Federal de Pelotas - UFPEL, RS. E-mail: josycantuaria@yahoo.com.br

\begin{abstract}
Seed companies use vigor tests in their internal seed quality control procedures. Therefore, it is necessary to choose effective methods to obtain quick responses for making decisions related to the handling, disposal and marketing of seed lots. Thus, the objective of this work was to adapt a methodology for the accelerated aging test in soybean seeds. Sixty-nine lots were used and the experimental design used was completely randomized, with four replications. For the initial characterization of the lots, water content was determined, germination test and field emergence. The soybean seed lots selected based on the initial characterization, were submitted to the standard accelerated aging methodology and twenty-one adapted methodologies. After the physiological characterization of the 69 lots, 24 lots with similar germination with different levels of vigor were selected. For adapted methodologies that used only distilled water inside the gerbox box, there was an increase in the water content of the seeds of all analyzed lots. However, all methodologies with the use of saline solution had a lower water content. The adapted methodologies $\mathrm{N}$ (pre-treatment in forced air oven at $35-40^{\circ} \mathrm{C}$ for two hours, BOD $42^{\circ} \mathrm{C}$ for 24 hours, using saline) and S (pretreatment in forced air oven at $35-40^{\circ} \mathrm{C}$ for two hours, BOD $45^{\circ} \mathrm{C}$ for 12 hours, with the use of distilled water) are the most suitable for use in the accelerated aging test for soybean crops, as they present relevant results in a shorter evaluation period.
\end{abstract}

Key words: Glycine max L.; quality control; lots; vigor.

\section{Adequação do teste de envelhecimento acelerado para sementes de soja}

\section{Resumo}

As empresas de sementes utilizam testes de vigor em seus procedimentos internos de controle de qualidade das sementes. Por isso, é necessário escolher métodos eficazes para obter respostas rápidas para a tomada de decisões relacionadas ao manuseio, descarte e comercialização de lotes de sementes. Assim o objetivo deste trabalho foi adaptar uma metodologia para o teste de envelhecimento acelerado em sementes de soja. Foram utilizados sessenta e nove lotes em um delineamento experimental inteiramente casualizado, com quatro repetições. Para a caracterização inicial dos lotes foi realizado a determinação do teor de água, teste de germinação e emergência a campo. Os lotes de sementes de soja selecionados com base na caracterização inicial, foram submetidos a metodologia padrão do envelhecimento acelerado e vinte e uma metodologias adaptadas. Após a caracterização fisiológica dos 69 lotes, foram selecionados 24 lotes com germinação semelhante com diferentes níveis de vigor. Para as metodologias adapatadas e que foram utilizadas apenas água destilada no interiro da caixinha de gerbox, ocorreu um aumento no teor de água das sementes de todos lotes analisados, entretanto, todas as metodologias com o uso de solução salina, apresentaram um teor de água menor. As metodologias adaptadas $\mathrm{N}$ (pré-tratamento em estufa de ar forçado a $35-40^{\circ} \mathrm{C}$ por duas horas, BOD $42^{\circ} \mathrm{C}$ por 24 horas, com o uso de solução salina) e $\mathrm{S}$ (prétratamento em estufa de ar forçado a $35-40^{\circ} \mathrm{C}$ por duas horas, $\mathrm{BOD} 45^{\circ} \mathrm{C}$ por 12 horas, com o uso de água destilada) são as mais indicadas para o uso no teste de envelhecimento acelerado para a cultura da soja, por apresentarem resultados relevantes em um menor período de avaliação.

Palavras-chave: Glycine max L. ; controle de qualidade; lotes; vigor. 


\section{Introduction}

The evaluation of the vigor of soybean seeds is important in the initial performance of the seedlings, guaranteeing the uniformity of a healthy and vigorous plant stand, to guarantee its productivity potential. For this it is necessary to carry out vigor analysis tests and currently, there are numerous methodologies. However, it is known that the accelerated aging test is one of the most used for soybean crops, as it provides a high level of stress to the seeds, with high temperature and high humidity (MATERA et al., 2019).

The test has its origin through the observation of the deterioration and death of seeds during storage, having its main cause for the coagulation of proteins and that the heating of the seed mass accelerated those processes; suggested conducting germination tests after exposing seeds to high temperatures for relatively short periods to estimate the storage potential of seed lots (MARCOS FILHO, 2015).

In addition to evaluating the seed storage potential for being an effective and rapid test, it corroborates for evaluating the seedling emergence potential in the field, in addition to identifying differences in physiological potential between similar germination samples. The accelerated aging test is part of the internal quality control of seed producing companies (SANTOS et al., 2017).

Performed according to the rate of deterioration of the seeds, it is considerably increased through its exposure to adverse levels of temperature and relative humidity, considered the environmental factors most related to the deterioration of the seeds (BINOTTI et al., 2008) it is important to consider in the test the difference in the water absorption by the seeds, because when exposed to the humid atmosphere there may be marked variations in their degree of humidity (TUNES et al., 2012).

Studies have shown that the exposure of seeds to $100 \%$ relative humidity can harm germination, as well as the development of seedlings, and can even compromise the fidelity of the results, being justified by the presence of microorganisms that directly harm the evaluations, causing uncertainties regarding the seedling normalities. That is why, it is possible to modify the relative humidity of the air, decreasing it to up to $55 \%$, according to the amount of $\mathrm{NaCl}$ used in the distilled water solution, being an alternative to the accelerated aging test with the use of saline solution (MARCOS FILHO, 2015).

Thus, the objective of this work was to adapt a methodology for the accelerated aging test in soybean seeds and to correlate with the emergence in the field.

\section{Material and methods}

The experiment was performed in the Seeds Analysis Teaching Laboratory (LDAS: Laboratório Didático de Análise de Sementes), belonging to the post-graduation program in Seeds Technology, Pelotas Federal University (FAEM/UFPel).

Soybean seeds were used, in partnership with Nidera Sementes, represented by sixty-nine seed lots.

\section{Experiment I (Characterization of lots)}

For the characterization of the lots, determinations and tests described below were carried:

Water content - determined according to the methodology prescribed in the Rules for Seed Analysis - RAS (Brazil, 2009), using the oven method at $105 \pm 3{ }^{\circ} \mathrm{C}$ for 24 hours, with the results being expressed as \% water content.

Germination test - four replications of 200 seeds were used for each batch, using germitest paper moistened with distilled water in a proportion of 2.5 times the weight of the dry paper, being conducted at a constant temperature of $25^{\circ} \mathrm{C}$. The evaluation was carried out on the eighth day after sowing, according to the criteria established in the RAS (BRAZIL, 2009), the results being expressed in percentage of normal seedlings.

Emergency field test - conducted on construction sites, with soil originating from the $A$ horizon of a planossol of the Pelotas mapping unit. Eight lines of 1.20 meters in length were used for each lot, with a spacing of ten centimeters between lines, with lots being randomly distributed on each line within the blocks. Sowing took place at the beginning of September, sowing 25 seeds per row and counting was performed 15 days after sowing, where the emergency stabilized.

\section{Experiment II (Adaptations of methodologies)}

he soybean seed lots selected based on the initial characterization, were subjected to the standard accelerated aging methodology and 21 adapted methodologies as shown in Table 1, 
modifying temperatures, periods and solutions, during pre-treatment and exposure in the BOD.

Table 1. Description of alternative methodologies for the accelerated aging test.

\begin{tabular}{|c|c|c|c|c|c|}
\hline SIGLA & PRE-TREATMENT ( ${ }^{\circ} \mathrm{C}$ ) & $\begin{array}{c}\text { TIME } \\
\text { COURSE } \\
\text { (Hours) }\end{array}$ & $\begin{array}{c}\text { TEMPERATURE } \\
\text { BOD }\left({ }^{\circ} \mathrm{C}\right)\end{array}$ & SOLUTION & $\begin{array}{c}\text { TIME COURSE } \\
\text { BOD } \\
\text { (Hours) }\end{array}$ \\
\hline STANDARD & - & - & 41 & Water & 72 \\
\hline 1 & Fridge (5-10) & 24 & 41 & Water & 24 \\
\hline 2 & Fridge (5-10) & 24 & 41 & Saline & 24 \\
\hline 3 & Fridge (5-10) & 24 & 42 & Water & 24 \\
\hline 4 & Fridge (5-10) & 24 & 42 & Saline & 24 \\
\hline 5 & Fridge (5-10) & 24 & 43 & Water & 24 \\
\hline 6 & Fridge $(5-10)$ & 24 & 43 & Saline & 24 \\
\hline 7 & Fridge (5-10) & 24 & 45 & Water & 24 \\
\hline 8 & Fridge (5-10) & 24 & 45 & Saline & 24 \\
\hline 9 & Fridge $(5-10)$ & 24 & 45 & Water & 12 \\
\hline 10 & Fridge $(5-10)$ & 24 & 45 & Saline & 12 \\
\hline 11 & Stove $(35-40)$ & 2 & 41 & Water & 24 \\
\hline 12 & Stove $(35-40)$ & 2 & 41 & Saline & 24 \\
\hline 13 & Stove (35-40) & 2 & 42 & Water & 24 \\
\hline 14 & Stove (35-40) & 2 & 42 & Saline & 24 \\
\hline 15 & Stove $(35-40)$ & 2 & 43 & Water & 24 \\
\hline 16 & Stove $(35-40)$ & 2 & 43 & Saline & 24 \\
\hline 17 & Stove (35-40) & 2 & 45 & Water & 24 \\
\hline 18 & Stove $(35-40)$ & 2 & 45 & Saline & 24 \\
\hline 19 & Stove $(35-40)$ & 2 & 45 & Water & 12 \\
\hline 20 & Stove (35-40) & 2 & 45 & Saline & 12 \\
\hline
\end{tabular}

Standard methodology - used a single layer of seeds, evenly distributed on a screen attached to the gerbox-type plastic boxes, containing 40 $\mathrm{mL}$ of distilled water. The boxes containing the seeds were covered and kept in a BOD chamber, at $41{ }^{\circ} \mathrm{C}$ for 72 hours. After this period, the aged seeds were submitted to the determination of the water content and to the germination test, according to the methodology previously described and the results expressed in percentage of normal seedlings for each lot.

Methodologies adapted according to Table 1- were made using "gerbox" plastic boxes (11.0 $\times 11.0 \times 3.5 \mathrm{~cm}$ ) as an individual compartment, having, suspended inside, an aluminum screen, where the seeds were evenly distributed. In each box were added $40 \mathrm{ml}$ of distilled water or saline solution $111 \mathrm{~g}$ of $\mathrm{NaCl}$ diluted in one liter of water, establishing an environment with approximately $88 \%$ relative humidity), adapting the methodology accordingly Jianhua and McDonald (1996). The covered boxes were subjected to pretreatment in a refrigerator with temperatures between $5-10{ }^{\circ} \mathrm{C}$ for a 24 -hour disposal period or pretreatment in a forced air circulation oven with alternating temperatures between $35-40{ }^{\circ} \mathrm{C}$ with disposal two hours. After pre-treatment, the boxes were placed in a germination chamber (type B.O.D. - Biochemical Oxigen Demand), regulated at temperatures of $41,42,43$ or $45{ }^{\circ} \mathrm{C}$ for a period of 12 or 24 hours. After each period the aged seeds were submitted to the determination of the water content and to the germination test exactly as was done in the physiological characterization. Performing the evaluations on the fifth day after sowing, according to the Rules for Seed Analysis (RAS) (BRAZIL, 2009), and the results expressed in percentage of normal seedlings for each lot.

\section{Experimental design and statistical analysis}

The experimental design used in the two experiments was completely randomized, with four replications. The data obtained were subjected to analysis of variance and the averages obtained from the evaluations of each 
batch were compared by the Scott-Knott test at a level of $5 \%$ probability, and for these analyzes the software SAS System was used.

Pearson's simple correlation coefficients $(r)$ were also calculated for the combinations of the accelerated aging test with the field emergency test, with the significance of the $r$ values determined by the $t$ test at $5 \%$ probability performed using the software Winstat.

\section{Results and Discussion}

After the physiological characterization of 69 lots, 24 lots with similar germination with different levels of vigor were selected.

The water content of the soybean seeds was similar for the 24 lots, with an average of $12.7 \%$ moisture according to Table 2 . The data obtained for the water content of the seeds, which are similar for the seeds being in the range of maximum acceptable amplitude, which is 1 to 3 percentage points (MARCOS FILHO, 1999). This fact is important for the performance of the accelerated aging evaluations, considering that the uniformity of the water content of the seeds is essential for the standardization of the evaluations and obtaining consistent results (MARCOS FILHO, 2005), within certain limits, the wetter seeds are more affected by the conditions of accelerated aging.

According to Tunes et al. (2011), when the water content of the seeds is relatively low, as occurred in the lots, greater reliability is allowed to the results obtained in the physiological quality tests. It can be analyzed that for the germination variable the lots do not differ (Table 2), as expected, as they present a high physiological quality. 
Table 2. Initial quality of the 24 selected with similar germination and different levels of vigor, with Germination (G) and Field Emergency (FI) tests

\begin{tabular}{|c|c|c|c|c|c|}
\hline Lot & Cultivar & Level & $W C(\%)$ & G (\%) & FI (\%) \\
\hline 3 & NS 7901 & High & 13.5 & $99 a$ & $97 a$ \\
\hline 8 & NS 7901 & High & 12.6 & $97 a$ & $98 \mathrm{a}$ \\
\hline 9 & NS 7901 & High & 11.4 & $96 a$ & $93 a$ \\
\hline 14 & NS 7901 & High & 13.4 & $97 a$ & $96 a$ \\
\hline 21 & NS 7901 & High & 12.4 & $97 a$ & $94 \mathrm{a}$ \\
\hline 2 & NS 7901 & Average & 12.3 & $97 a$ & $86 \mathrm{~b}$ \\
\hline 5 & NS 7901 & Average & 12.1 & $97 a$ & $85 \mathrm{~b}$ \\
\hline 10 & NS 7901 & Average & 13.0 & $98 a$ & $85 \mathrm{~b}$ \\
\hline 11 & NS 7901 & Average & 12.9 & $95 a$ & $86 \mathrm{~b}$ \\
\hline 12 & NS 7901 & Average & 11.8 & $96 a$ & $85 \mathrm{~b}$ \\
\hline 13 & NS 7901 & Average & 12.7 & $99 a$ & $85 \mathrm{~b}$ \\
\hline 15 & NS 7901 & Average & 12.5 & $98 a$ & $85 \mathrm{~b}$ \\
\hline 17 & NS 7901 & Average & 11.8 & $95 a$ & $87 \mathrm{~b}$ \\
\hline 18 & NS 7901 & Average & 12.3 & $97 a$ & $88 \mathrm{~b}$ \\
\hline 23 & NS 7901 & Average & 12.8 & $96 a$ & $87 \mathrm{~b}$ \\
\hline 24 & NS 7901 & Average & 13.6 & $96 a$ & $86 \mathrm{~b}$ \\
\hline 1 & NS 7901 & low & 11.8 & $97 a$ & $81 \mathrm{c}$ \\
\hline 4 & NS 7901 & low & 11.1 & $94 \mathrm{a}$ & $81 \mathrm{c}$ \\
\hline 6 & NS 7901 & low & 13.1 & $97 a$ & $81 \mathrm{c}$ \\
\hline 7 & NS 7901 & low & 12.5 & $96 a$ & $78 \mathrm{c}$ \\
\hline 16 & NS 7901 & low & 13.6 & $97 a$ & $82 \mathrm{c}$ \\
\hline 19 & NS 7901 & low & 13.9 & $96 a$ & $81 \mathrm{c}$ \\
\hline 20 & NS 7901 & low & 13.7 & $94 a$ & $82 \mathrm{c}$ \\
\hline 22 & NS 7901 & low & 13.2 & $95 \mathrm{a}$ & $80 \mathrm{c}$ \\
\hline & & & ---- & 3.01 & 8.16 \\
\hline
\end{tabular}

Lower case equal letters in the column do not differ significantly at the level of $5 \%$ probability of error by the ScottKnott cluster model ( $*$ significant at the level of $5 \%$ probability. Ns = not significant).

For the field emergency variable. which is considered one of the main tests of vigor for being carried out in climatic conditions closer to reality for the studied crop that will face in the sowing in the field. It is noted that the lots present a significant difference between them, differing in high lots, medium and low vigor. This confirms the stratification of the lots. separating as to their vigor levels.

The high vigor batches were those that presented a physiological potential in the emergency field test between 100 and $92 \%$ of emergencies, with batches $3,8,9,14$ and 21 (Table 2). For the 11 medium vigor batches, we quantify their physiological potentials on the average of 91 to $85 \%$ regarding the field emergency test, batches $2,5,10,11,12,13,15$, $17,18,23$ and 24 . Finally, the low vigor batches showed a physiological development in the emergency test in the field between 84 and $75 \%$, identified as lots $1,4,6,7,16,19,20$ and 22.

The uniformity of seedling emergence can 
be influenced by the variation in the degree of soil moisture, presence of surface residues, temperature, sower conditions as: seed depth and distribution, and physiological potential of the seed lot (MARCOS FILHO, 2015). Egli and Rucker (2012) evaluated high germination lots, however with differences in vigor, positively corroborating the difference between the emergency uniformity index, however the authors believe that this difference can be influenced by temperature, humidity and sowing depth, affecting much more the uniformity of the than vigor.

Differences in the initial development of plants from seed lots with variations in the level of vigor emphasize the speed, uniformity and intensity of growth of seedlings and plants, reflected in the ability to compete for water, light and nutrients, especially with invasive plants, constituting one of the main causes of the fall in crop productivity (MARCOS FILHO, 2015).

Germination is a process that comprises the absorption of water, mobilization of stored reserves and the resumption of embryonic growth, giving rise to a seedling. This develops at the expense of the reserves contained in the endosperm or cotyledon tissue, although nutrient absorption from the soil may occur from the protrusion of the primary root; this situation lasts until the stage when the plant acquires sufficient photosynthetic efficiency to become autotrophic (SCHOSSLER et al., 2012).

The influence of seed vigor on the emergence of seedlings in the field, the establishment of the stand and the initial development of plants leaves no doubt, both among the scientific community and in the productive sector, especially under less favorable environmental conditions. Only the recognition of the importance of these effects would be sufficient to justify the use of more vigorous seed lots, as an initial step towards obtaining compensating agricultural yields. (BRAZ; ROSSETTO, 2009).

It is understood that, during the seedling phase and the beginning of the plant's development, vigor can be responsible for a considerable boost to growth; the reserves accumulated during the development of seeds and their mobilization during germination are responsible for the initial growth of seedlings and plants, but this period of influence is relatively short and the dimension of the persistence of this initial effect is less evident during the subsequent stages of development (HENNING et al., 2010).

Most of the plant's component tissues involved in the accumulation of dry matter are formed after seedling emergence; therefore, as the stages succeed, this influence tends to be less and less, until they become less expressive, from the beginning of the reproductive phase of the plant. Thus, it is observed that no matter how much the seed lot has similar germination, it does not mean that it has its full physiological development, where stress conditions can decrease the vigor of the seeds, through a greater disorganization of the seed membranes. In other words, a seed with high germination and vigor, its structures are more organized and protected than a seed with high germination and low vigor, directly affecting the uniformity of the development of an initial stand (MARCOS FILHO, 2015).

Thus, it can be said that lots with similar germination or with values that do not differ from each other statistically, do not necessarily have the same vigor or similar values between the lots, regardless of whether they are of the same cultivar or not, because the lots, however much they have equal conditions from sowing to harvest, may present small differences in levels of adversity or stress that may justify the difference in vigor in physiological quality.

Regarding the water content of the seeds after accelerated aging, it is observed that for the standard methodology, the average water content of the seeds in the soybean lots was 21.9\% (Table 3). However, all the methodologies with the use of saline solution, presented a lower water content, for providing an environment with a relative humidity of around $88 \%$.

The viability of the seeds and their longevity depends on the interaction of several factors, among which the degree of humidity occupies a prominent place. The knowledge of the water content of the seeds, at all stages of the production process, has a high importance for quality control. Thus, frequent determinations of the degree of humidity are necessary to establish and adopt indicated procedures to avoid or minimize the damages that frequently occur in the seeds. (MARCOS FILHO, 2015). The verification of the consistency of the results is carried out by the deterioration of the water content of the seeds before and after the aging period.

In the first case, it must be ensured that the test is installed with samples whose water 
content does not vary by more than two percentage points, as the wetter ones are more sensitive to the test conditions and, therefore, subject to more intense deterioration. At the end of aging, this same variation is tolerated between the water content of the aged seeds, indicating uniformity of the test (MARCOS FILHO, 1999).

Seeds submitted to accelerated aging with the use of saline solution. generally reach water content around $11.0 \%$ to $14.0 \%$, closer to those verified during the storage of the seeds of most cultivated species. According to Marcos Filho (2015), methodologies with alternatives for the use of saline solution present water contents of up to 15 percentage points above the initial water content of the seeds, as we can see in the methodologies that we use saline solution. 
Table 3. Description of the water content realized after the seeds submitted to each methodology of the accelerated aging test

\begin{tabular}{|c|c|c|c|c|c|c|c|c|c|c|c|c|c|c|c|c|c|c|c|c|c|}
\hline Lot & Standard & 1 & 2 & 3 & 4 & 5 & 6 & 7 & 8 & 9 & 10 & 11 & 12 & 13 & 14 & 15 & 16 & 17 & 18 & 19 & 20 \\
\hline 3 & 22.3 & 30.6 & 20.2 & 1.7 & 21.3 & 31.3 & 28.4 & 26.9 & 23.9 & 26.9 & 23.9 & 30.0 & 23.3 & 29.2 & 28.7 & 32.1 & 19.3 & 34.7 & 27.2 & 29.6 & 27.7 \\
\hline 8 & .4 & 29.5 & 22.0 & 32.3 & 22.7 & 35.1 & 18.8 & 29.7 & 22.3 & 29.7 & 22.3 & 27.5 & 21.5 & 29.2 & 20.5 & 28.4 & 22.7 & 30.5 & 22.9 & 29.4 & 27.5 \\
\hline 9 & .8 & 29.9 & 18.6 & 31.1 & 22.7 & 32.8 & 31.7 & 28.4 & 21.0 & 28.4 & 21.0 & 27.4 & 26.1 & 24.5 & 22.6 & 30.0 & 20.6 & 29.0 & 25.5 & 30.5 & 31.2 \\
\hline 14 & .7 & 32.6 & 19.8 & 24.4 & 22.4 & 33.2 & 23.9 & 28.3 & 22.3 & 28.3 & 22.3 & 25.5 & 22.3 & 28.1 & 23.1 & 27.4 & 20.3 & 24.4 & 30.6 & 30.1 & 29.3 \\
\hline 21 & & 36.1 & 21.2 & 28.9 & 23.1 & 27.1 & 27.3 & 27.7 & 23.1 & 27.7 & 23.1 & 27.5 & 24.3 & 29.4 & 22.5 & 30.3 & 21.5 & 28.6 & 23.8 & 31.8 & 27.5 \\
\hline 2 & 4 & 36.5 & 19.5 & 1.4 & 22.2 & 30.8 & 24.9 & 31.7 & 21.2 & 31.7 & 21.2 & 25.9 & 24.1 & 30.2 & 23.1 & 30.3 & 23.9 & 31.4 & 25.5 & 30.4 & 29.3 \\
\hline 5 & .5 & 31.1 & 18.9 & 32.1 & 23.0 & 30.5 & 21.0 & 28.1 & 22.0 & 28.1 & 22.0 & 28.1 & 23.7 & 30.0 & 23.4 & 29.5 & 22.8 & 25.8 & 24.2 & 29.7 & 29.2 \\
\hline 10 & 22.6 & 31.0 & 24.7 & 31.3 & 24.0 & 27.6 & 24.3 & 31.7 & 21.2 & 31.7 & 21.2 & 29.0 & 18.6 & 26.3 & 22.6 & 34.6 & 21.8 & 30.7 & 22.9 & 32.9 & 28.4 \\
\hline 11 & & 28.2 & 20.5 & 35.2 & 19.7 & 36.2 & 20.5 & 30.2 & 21.0 & 30.2 & 21.0 & 25.9 & 27.9 & 26.8 & 24.8 & 18.7 & 23.9 & 28.5 & 24.2 & 29.3 & 29.5 \\
\hline 12 & 3 & 31.7 & 24.6 & 30.8 & 22.3 & 38.0 & 25.8 & 34.6 & 20.2 & 34.6 & 20.2 & 26.8 & 20.1 & 28.0 & 24.7 & 30.9 & 22.0 & 28.0 & 31.0 & 30.4 & 30.2 \\
\hline 13 & & 29.0 & 25.4 & 1.2 & 21.3 & 32.0 & 21.2 & 28.5 & 20.1 & 28.5 & 20.1 & 28.5 & 22.0 & 26.8 & 21.0 & 25.4 & 21.2 & .5 & 27.2 & 27.1 & 27.6 \\
\hline 15 & & 32.3 & 19.8 & 32.6 & 24.3 & 28.9 & 25.5 & 29.9 & 21.0 & 29.9 & 21.0 & 31.0 & 24.9 & 28.2 & 21.8 & 32.3 & 22.9 & 31.3 & 26.1 & 32.3 & 29.6 \\
\hline 17 & & 29.2 & 21.6 & 37.1 & 22.8 & 30.9 & 19.9 & 32.0 & 25.0 & 32.0 & 25.0 & 30.1 & 26.2 & 28.9 & 20.4 & 33.4 & 22.2 & 1.8 & 23.6 & 33.6 & 26.9 \\
\hline 18 & & 4.1 & 19.3 & 32.4 & 23.2 & 35.0 & 22.2 & 33.3 & 16.0 & 33.3 & 16.0 & 30.3 & 25.8 & 29.5 & 24.4 & 21.7 & 21.9 & 30.3 & 22.6 & 32.5 & 32.1 \\
\hline 23 & 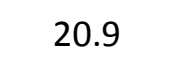 & 35.6 & 21.2 & 30.2 & 27.5 & 33.8 & 23.2 & 34.2 & 21.3 & 34.2 & 21.3 & 30.7 & 23.1 & 29.2 & 25.5 & 21.6 & 22.0 & 32.0 & 24.7 & 30.4 & 30.8 \\
\hline 24 & & 35.2 & 21.6 & 27.4 & 26.0 & 32.8 & 28.0 & 25.9 & 24.0 & 25.9 & 24.0 & 33.8 & 22.2 & 29.9 & 30.6 & 34.8 & 22.5 & 27.5 & 25.6 & 29.8 & 25.6 \\
\hline 1 & 1.3 & 29.6 & 23.5 & 26.8 & 21.3 & 26.9 & 22.8 & 32.2 & 20.6 & 32.2 & 20.6 & 27.2 & 20.2 & 26.9 & 24.1 & 30.1 & 23.0 & 28.9 & 30.4 & 32.5 & 32.4 \\
\hline 4 & & 27.9 & 21.1 & 28.2 & 23.9 & 32.6 & 23.9 & 33.4 & 23.2 & 33.4 & 23.2 & 27.1 & 23.4 & 30.4 & 22.6 & 31.1 & 23.6 & 26.4 & 30.7 & 32.8 & 30.5 \\
\hline 6 & & 33.1 & 18.5 & 2.9 & 20.5 & 28.9 & 23.9 & 34.6 & 22.1 & 34.6 & 22.1 & 24.2 & 24.9 & 30.5 & 14.7 & 30.6 & 21.2 & 28.0 & 21.5 & 31.5 & 27.5 \\
\hline 7 & 21.9 & 28.2 & 18.2 & 31.3 & 23.4 & 33.3 & 21.8 & 30.5 & 21.0 & 30.5 & 21.0 & 27.5 & 21.6 & 28.4 & 22.3 & 26.5 & 21.7 & 26.4 & 23.8 & 28.9 & 28.8 \\
\hline 16 & 2 & 36.1 & 26.5 & 33.5 & 24.1 & 28.3 & 22.9 & 33.0 & 21.9 & 33.0 & 21.9 & 31.9 & 36.3 & 24.0 & 24.7 & 32.1 & 23.1 & 32.2 & 24.9 & 29.6 & 28.4 \\
\hline 19 & 22.1 & 27.7 & 21.9 & 29.2 & 20.4 & 33.2 & 22.1 & 35.0 & 20.5 & 35.0 & 20.5 & 27.3 & 18.1 & 21.8 & 23.3 & 26.1 & 21.6 & 29.6 & 23.2 & 33.2 & 28.4 \\
\hline 20 & 23.0 & 29.3 & 16.8 & 28.1 & 25.9 & 23.6 & 22.6 & 27.2 & 22.6 & 27.2 & 22.6 & 26.5 & 25.1 & 30.7 & 26.9 & 26.3 & 20.5 & 27.0 & 24.1 & 29.9 & 29.3 \\
\hline 22 & & 32.1 & 21.6 & 29.4 & 22.7 & 28.6 & 26.7 & 34.1 & 18.9 & 34.1 & 18.9 & 29.3 & 25.7 & 27.2 & 23.1 & 29.8 & 22.8 & 33.7 & 24.9 & 29.7 & 32.1 \\
\hline erag & 1.9 & 31.5 & 1.1 & 33.7 & 22.9 & 31.3 & 23.9 & 30.9 & 21.5 & 30.9 & 21.5 & 28.3 & 23.8 & 28.1 & 23.4 & 28.9 & 22.0 & 29.3 & 25.5 & 30.7 & 29.2 \\
\hline
\end{tabular}


Table 4 shows the results of the methodological adaptations of the accelerated aging test.

The methodology named as "standard" is the most used for the cultivation of soy in the internal control of companies and in research. There was a statistically significant difference for this variable, however, it did not correspond to the stratification of the lots in Table 2. However, the high vigor lots remained with the highest averages. The low and medium vigor lots did not show any similarity, which can be explained by the high level of stress to which the seeds were exposed.

In studies by Vanzolini et al. (2002), the usual accelerated aging test for soybean crops, did not stratify the lots as to the level of vigor. The same occurred with the results found in the soybean culture by Aguero et al. (1997), however, the evaluation occurred with different cultivars and with the germination variable with significant difference between them.

For the other methodologies, all showed a significant difference between the lots, but they did not corroborate with the stratification of the initial quality. However, the high vigor batches showed a physiological performance similar to Table 2, mainly in methodologies 1 (pretreatment in refrigerator $5-10{ }^{\circ} \mathrm{C}$ for 24 hours, BOD $41{ }^{\circ} \mathrm{C}$ for 24 hours, with the use of distilled water), and methodology 9 (pre-treatment in refrigerator $5-10{ }^{\circ} \mathrm{C}$ for 24 hours, BOD $45^{\circ} \mathrm{C}$ for 12 hours, using distilled water).

The other methodologies that can be highlighted for the accelerated aging test, referring to the behavior of the batches already identified as high vigor are methodologies 8 (pretreatment in refrigerator $5-10{ }^{\circ} \mathrm{C}$ for 24 hours, BOD $45^{\circ} \mathrm{C}$ for 24 hours, using distilled water). Methodology 10 (pre-treatment in forced air oven at $35-40{ }^{\circ} \mathrm{C}$ for two hours, BOD $45^{\circ} \mathrm{C}$ for 12 hours, using saline) and methodology 12 (pretreatment in forced air oven at $35-40^{\circ} \mathrm{C}$ for two hours, BOD $41^{\circ} \mathrm{C}$ for 24 hours, using saline). Tunes et al., (2012) working with broccoli seeds (Brassica oleracea var. Italica), finds that the exposure of seeds to accelerated aging using saturated $\mathrm{NaCl}$ solution for 48 hours proved to be the most appropriate, as the shortest period of execution is a desirable feature in a vigor test. 
Table 4. Average results obtained by 21 methodologies of the accelerated aging test (\%) in 24 soybean seed lots

\begin{tabular}{|c|c|c|c|c|c|c|c|c|c|c|c|c|c|c|c|c|c|c|c|c|c|c|}
\hline Lots & Level & Standard & 1 & 2 & 3 & 4 & 5 & 6 & 7 & 8 & 9 & 10 & 11 & 12 & 13 & 14 & 15 & 16 & 17 & 18 & 19 & 20 \\
\hline 3 & High & $92 a$ & $84 a$ & $81 \mathrm{~b}$ & $74 \mathrm{c}$ & $70 \mathrm{c}$ & $69 \mathrm{c}$ & $81 \mathrm{~b}$ & $49 d$ & $63 c$ & $89 a$ & $89 a$ & $89 a$ & $85 \mathrm{~b}$ & $46 \mathrm{f}$ & $82 \mathrm{~b}$ & $64 \mathrm{~b}$ & $52 \mathrm{f}$ & $54 \mathrm{~d}$ & $49 c$ & $83 \mathrm{~b}$ & $84 \mathrm{~b}$ \\
\hline 8 & High & $85 \mathrm{~b}$ & $76 \mathrm{~b}$ & $65 d$ & $73 c$ & $52 \mathrm{e}$ & $68 c$ & $71 d$ & $49 \mathrm{~d}$ & $71 b$ & $86 a$ & $77 c$ & $73 d$ & $79 \mathrm{~b}$ & $81 \mathrm{c}$ & $85 b$ & $48 c$ & $64 d$ & 51 e & $76 a$ & $73 \mathrm{c}$ & $66 d$ \\
\hline 9 & High & $91 \mathrm{a}$ & $90 \mathrm{a}$ & $72 c$ & $86 \mathrm{~b}$ & $82 \mathrm{~b}$ & $84 a$ & $87 a$ & $72 b$ & $86 a$ & $89 a$ & $89 a$ & $85 \mathrm{~b}$ & $88 \mathrm{a}$ & $89 \mathrm{~b}$ & $93 a$ & $88 \mathrm{a}$ & $83 \mathrm{~b}$ & $71 \mathrm{c}$ & $68 \mathrm{~b}$ & $85 \mathrm{~b}$ & $88 \mathrm{a}$ \\
\hline 14 & High & $89 a$ & $86 a$ & $66 \mathrm{~d}$ & $78 c$ & $69 c$ & $71 \mathrm{~b}$ & $74 \mathrm{c}$ & $65 c$ & $86 a$ & $88 \mathrm{a}$ & $85 \mathrm{~b}$ & $79 c$ & $90 \mathrm{a}$ & $89 \mathrm{~b}$ & $86 b$ & $71 \mathrm{~b}$ & $75 \mathrm{c}$ & $66 c$ & $71 b$ & $81 \mathrm{~b}$ & $81 \mathrm{~b}$ \\
\hline 21 & High & $90 \mathrm{a}$ & $87 a$ & $72 c$ & $83 \mathrm{~b}$ & $70 c$ & $72 \mathrm{~b}$ & $74 c$ & $72 b$ & $86 \mathrm{a}$ & $84 \mathrm{~b}$ & $87 \mathrm{a}$ & $86 \mathrm{~b}$ & $92 \mathrm{a}$ & $87 \mathrm{~b}$ & $85 \mathrm{~b}$ & $49 c$ & $85 \mathrm{~b}$ & $47 \mathrm{e}$ & $52 \mathrm{c}$ & 33 b & $4 \mathrm{~b}$ \\
\hline 2 & Average & $83 \mathrm{~b}$ & $92 \mathrm{a}$ & $72 c$ & $88 \mathrm{~b}$ & $55 \mathrm{e}$ & $84 a$ & $84 \mathrm{~b}$ & $64 c$ & $72 b$ & $86 a$ & $85 \mathrm{~b}$ & $86 \mathrm{~b}$ & $88 \mathrm{a}$ & $71 \mathrm{~d}$ & $63 \mathrm{~d}$ & $72 \mathrm{~b}$ & $66 \mathrm{~d}$ & $36 \mathrm{f}$ & $53 c$ & $86 \mathrm{~b}$ & $77 c$ \\
\hline 5 & Average & $83 \mathrm{~b}$ & $78 b$ & $79 \mathrm{~b}$ & $66 \mathrm{~d}$ & $53 \mathrm{e}$ & $74 \mathrm{~b}$ & $83 \mathrm{~b}$ & $67 c$ & $83 a$ & $81 \mathrm{~b}$ & $76 c$ & $73 d$ & $85 b$ & $83 c$ & $84 b$ & $70 \mathrm{~b}$ & $72 c$ & $66 c$ & $48 c$ & $85 b$ & $81 \mathrm{~b}$ \\
\hline 10 & Average & $91 \mathrm{a}$ & $89 a$ & $91 \mathrm{a}$ & $87 b$ & 91 a & $80 \mathrm{a}$ & $88 \mathrm{a}$ & $70 c$ & $87 a$ & $88 \mathrm{a}$ & $92 \mathrm{a}$ & 91 a & $90 \mathrm{a}$ & 93 a & $90 \mathrm{a}$ & 89 a & $84 \mathrm{~b}$ & $88 a$ & $83 a$ & 94 a & $86 a$ \\
\hline 11 & Average & $88 a$ & $69 c$ & $67 d$ & $79 c$ & $64 \mathrm{~d}$ & $55 d$ & $69 d$ & $65 c$ & $71 b$ & $78 \mathrm{~b}$ & $82 c$ & $85 \mathrm{~b}$ & $84 \mathrm{~b}$ & $87 \mathrm{~b}$ & $86 b$ & $67 \mathrm{~b}$ & $72 c$ & $76 b$ & $70 \mathrm{~b}$ & $72 c$ & $77 c$ \\
\hline 12 & Average & $55 \mathrm{e}$ & $56 \mathrm{~d}$ & $51 \mathrm{e}$ & $52 \mathrm{e}$ & $19 \mathrm{~h}$ & $25 f$ & $41 \mathrm{f}$ & $33 \mathrm{e}$ & $48 d$ & $63 d$ & $49 \mathrm{e}$ & $74 c$ & $63 \mathrm{e}$ & $68 \mathrm{e}$ & $27 \mathrm{~g}$ & $24 d$ & $29 \mathrm{~g}$ & $10 i$ & $23 d$ & $48 \mathrm{f}$ & $49 \mathrm{e}$ \\
\hline 13 & Average & 94 a & $84 a$ & $73 c$ & $75 c$ & $78 \mathrm{~b}$ & 85 a & $81 \mathrm{~b}$ & $84 a$ & $75 b$ & 89 a & $85 b$ & 90 a & $81 \mathrm{~b}$ & $90 \mathrm{a}$ & $87 \mathrm{~b}$ & $73 \mathrm{~b}$ & $78 \mathrm{~b}$ & $59 d$ & $82 a$ & $72 c$ & $89 a$ \\
\hline 15 & Average & $87 a$ & $89 a$ & $74 \mathrm{c}$ & $75 \mathrm{c}$ & $64 \mathrm{~d}$ & 85 a & $81 \mathrm{~b}$ & $74 \mathrm{~b}$ & $81 \mathrm{a}$ & $84 \mathrm{~b}$ & $88 a$ & 90 a & $91 \mathrm{a}$ & $88 \mathrm{~b}$ & $86 b$ & $71 \mathrm{~b}$ & $81 \mathrm{~b}$ & $65 c$ & $73 b$ & $8 \mathrm{~b}$ & $82 \mathrm{~b}$ \\
\hline 17 & Average & $81 \mathrm{~b}$ & $71 c$ & $65 \mathrm{~d}$ & $66 \mathrm{~d}$ & $46 \mathrm{f}$ & $56 \mathrm{~d}$ & $71 \mathrm{~d}$ & $52 \mathrm{~d}$ & $51 \mathrm{~d}$ & $67 \mathrm{~b}$ & $66 \mathrm{~d}$ & $83 \mathrm{~b}$ & $75 c$ & $79 c$ & $79 \mathrm{~b}$ & $64 \mathrm{~b}$ & $69 c$ & $30 \mathrm{~g}$ & $64 \mathrm{~b}$ & $54 \mathrm{e}$ & $64 d$ \\
\hline 18 & Average & 92 a & $89 a$ & $90 \mathrm{a}$ & 94 a & $82 \mathrm{~b}$ & 75 b & 89 a & $75 b$ & $85 a$ & $89 a$ & $85 \mathrm{~b}$ & $88 \mathrm{a}$ & $90 \mathrm{a}$ & $94 \mathrm{a}$ & $90 a$ & 85 a & $88 \mathrm{a}$ & $61 \mathrm{~d}$ & $83 a$ & $86 b$ & $91 \mathrm{a}$ \\
\hline 23 & Average & 90 a & $84 a$ & $80 \mathrm{~b}$ & 91 a & $69 c$ & $83 a$ & $84 \mathrm{~b}$ & $83 a$ & $61 \mathrm{c}$ & $82 \mathrm{~b}$ & $84 b$ & $85 \mathrm{~b}$ & $88 a$ & $93 \mathrm{a}$ & $84 b$ & $83 a$ & $74 c$ & $71 c$ & $69 \mathrm{~b}$ & $86 b$ & $91 \mathrm{a}$ \\
\hline 24 & Average & $79 \mathrm{~b}$ & $73 c$ & $70 c$ & $79 c$ & 51 e & $70 \mathrm{c}$ & $83 \mathrm{~b}$ & $51 \mathrm{~d}$ & $74 \mathrm{~b}$ & $87 a$ & $81 b$ & $68 d$ & $72 c$ & $85 \mathrm{~b}$ & $68 c$ & $62 \mathrm{~b}$ & $70 \mathrm{c}$ & $62 d$ & $70 \mathrm{~b}$ & $72 c$ & $69 \mathrm{~d}$ \\
\hline 1 & low & $82 \mathrm{~b}$ & $74 c$ & $70 \mathrm{c}$ & $73 c$ & $43 \mathrm{f}$ & $85 a$ & $75 c$ & $66 c$ & $84 \mathrm{a}$ & $84 \mathrm{~b}$ & $91 \mathrm{a}$ & $82 \mathrm{~b}$ & $81 \mathrm{~b}$ & $64 \mathrm{e}$ & $71 \mathrm{c}$ & $68 \mathrm{~b}$ & $49 \mathrm{f}$ & $44 \mathrm{e}$ & $72 b$ & $73 c$ & $80 \mathrm{~b}$ \\
\hline 4 & low & 88 a & $71 c$ & $87 a$ & $75 \mathrm{c}$ & $30 \mathrm{~g}$ & $73 \mathrm{~b}$ & $76 \mathrm{c}$ & $46 \mathrm{~d}$ & $63 c$ & $85 \mathrm{~b}$ & $72 c$ & $75 c$ & $67 d$ & $64 \mathrm{e}$ & $84 \mathrm{~b}$ & $51 \mathrm{c}$ & $67 d$ & $48 \mathrm{e}$ & $49 c$ & $56 \mathrm{e}$ & $74 \mathrm{c}$ \\
\hline 6 & low & $75 c$ & $54 \mathrm{~d}$ & $27 \mathrm{f}$ & $47 \mathrm{f}$ & $25 \mathrm{~g}$ & $54 \mathrm{~d}$ & $46 \mathrm{e}$ & $49 \mathrm{~d}$ & $63 c$ & $71 b$ & $74 c$ & $38 \mathrm{e}$ & $50 \mathrm{f}$ & $47 \mathrm{f}$ & $44 \mathrm{f}$ & $31 \mathrm{~d}$ & $47 \mathrm{f}$ & $19 \mathrm{~h}$ & $28 \mathrm{~d}$ & $47 \mathrm{f}$ & $50 \mathrm{e}$ \\
\hline 7 & low & $67 \mathrm{~d}$ & $48 d$ & $31 \mathrm{f}$ & $35 \mathrm{~g}$ & $25 \mathrm{~g}$ & $32 \mathrm{e}$ & $45 \mathrm{e}$ & $14 \mathrm{f}$ & $23 \mathrm{e}$ & $40 \mathrm{e}$ & $48 \mathrm{e}$ & $21 \mathrm{f}$ & $63 \mathrm{e}$ & $33 \mathrm{~g}$ & $21 \mathrm{~h}$ & $23 d$ & $21 \mathrm{~h}$ & $10 i$ & $14 \mathrm{e}$ & $32 \mathrm{~g}$ & $24 f$ \\
\hline 16 & low & $95 \mathrm{a}$ & $89 a$ & $93 \mathrm{a}$ & $85 \mathrm{~b}$ & $74 \mathrm{c}$ & $84 \mathrm{a}$ & $84 \mathrm{~b}$ & $78 b$ & $84 \mathrm{a}$ & $91 \mathrm{a}$ & $83 \mathrm{~b}$ & 91 a & $91 \mathrm{a}$ & $92 \mathrm{a}$ & $91 \mathrm{a}$ & 89 a & 91 a & $83 \mathrm{a}$ & $70 \mathrm{~b}$ & $87 \mathrm{~b}$ & $86 \mathrm{a}$ \\
\hline 19 & low & $72 \mathrm{c}$ & $87 a$ & $59 \mathrm{~d}$ & $65 \mathrm{~d}$ & $52 \mathrm{e}$ & $65 c$ & $68 \mathrm{~d}$ & $62 c$ & $46 d$ & $80 \mathrm{~b}$ & $75 \mathrm{c}$ & $71 \mathrm{~d}$ & $81 \mathrm{~b}$ & $84 \mathrm{c}$ & $54 \mathrm{e}$ & $58 \mathrm{~b}$ & 59 e & $29 \mathrm{~g}$ & $50 \mathrm{c}$ & $64 \mathrm{~d}$ & $49 \mathrm{e}$ \\
\hline 20 & low & $80 \mathrm{~b}$ & $56 \mathrm{~d}$ & $26 \mathrm{f}$ & 55 e & $46 \mathrm{f}$ & $65 c$ & $66 \mathrm{~d}$ & $63 c$ & $50 \mathrm{~d}$ & $71 \mathrm{c}$ & $65 \mathrm{~d}$ & $71 \mathrm{~d}$ & $75 c$ & $72 \mathrm{~d}$ & $11 \mathrm{i}$ & $65 \mathrm{~b}$ & $71 \mathrm{c}$ & $47 \mathrm{e}$ & $66 \mathrm{~b}$ & $59 \mathrm{e}$ & $72 \mathrm{c}$ \\
\hline 22 & low & $86 \mathrm{~b}$ & $66 c$ & $67 d$ & $71 \mathrm{c}$ & $55 \mathrm{e}$ & $58 d$ & $76 c$ & $62 c$ & $59 c$ & $85 \mathrm{~b}$ & $81 \mathrm{~b}$ & $85 \mathrm{~b}$ & $87 a$ & $83 c$ & $70 \mathrm{c}$ & $72 \mathrm{~b}$ & $68 c$ & $51 \mathrm{e}$ & $71 \mathrm{~b}$ & $72 c$ & $75 \mathrm{c}$ \\
\hline Average & & 4.82 & 6.9 & 8.08 & 5.93 & 7.5 & 5.04 & 4.48 & 6.81 & 5.56 & 4.94 & 4.4 & 5.1 & 4.36 & 4.61 & 5.26 & 11.17 & 5.39 & 8.64 & 8.53 & 5.65 & 4.31 \\
\hline
\end{tabular}

Lower case equal letters in the column do not differ significantly at the level of $5 \%$ probability of error by the Scott-Knott cluster model $(*$ significant at the level of $5 \%$ probability. $\mathrm{Ns}=$ not significant). 
Analyzing the low vigor lots according to the initial quality already described in this work, by observing their results in Table 4, it can be said that all the methodologies were effective for these lots, as they all obtained a low development, highlighting mainly the methodology 4. The other methodologies that have a similar behavior were the adapted methodologies 3, 6, 7, 13, 16, 17 and 19.

Seed vigor assessment is essential in any seed quality control program, providing useful information for detecting and resolving problems at different levels of the production process, as well as on seed performance (COSTA et al., 2008).

To corroborate with the results MARCOS FILHO (2015) affirms the importance of verifying the water content after the aging period, where for the soybean crop the percentage must be 27 $35 \%$, which may present a variation of higher percentage points or lower. As the methodologies with better performances presented in this work.

The use of saline solution reduces the speed of water intake and the intensity of deterioration causes less drastic effects on the seeds and less variable results, as it avoids the additional effect of the action of microorganisms (MARCOS FILHO, 2015).

Table 5 presents data on the correlation of related variables from 21 methodologies for the accelerated aging vigor test of the 24 soybean seed lots correlated with the field emergency test, as it is considered the vigor test that presents similar conditions to the field. Thus, it can be seen that only three of all the tested methodologies do not have a significant correlation, namely: methodology 5, 7 and 15 .

Methodologies 2, 13 and 18 were significant by $t$ test at a level of $5 \%$ probability of error. with the linear coefficient at the following values: 0.2558 ; 0.2139 and 0.2566 , respectively.

Table 5. Linear correlations [Pearson's correlation coefficient (r)] between the 21 methodologies of the accelerated aging test with field emergence

\begin{tabular}{|c|c|c|c|c|c|}
\hline \multirow[t]{2}{*}{ Variable } & \multicolumn{4}{|c|}{ Accelerated aging } & \\
\hline & \multicolumn{4}{|c|}{ Standard } & \\
\hline $\mathrm{FE}$ & \multicolumn{4}{|c|}{$0.3203^{* *}$} & \\
\hline \multicolumn{6}{|c|}{ Pre-Treatment (Fridge 5-10C) } \\
\hline & 1 & 2 & 3 & 4 & 5 \\
\hline \multirow[t]{2}{*}{ FE } & $0.3697^{*}$ & $0.2558^{*}$ & $0.3725^{*}$ & $0.4121^{*}$ & $0.1903^{\mathrm{ns}}$ \\
\hline & 6 & 7 & 8 & 9 & 10 \\
\hline $\mathrm{FE}$ & $0.2701^{*}$ & $0.1295^{\mathrm{ns}}$ & $0.3772 *$ & $0.3898 *$ & $0.3393^{*}$ \\
\hline \multicolumn{6}{|c|}{ Pre-Treatment (Forced air greenhouse $35-40 \circ \mathrm{C}$ ) } \\
\hline \multirow{3}{*}{ FE } & 11 & 12 & 13 & 14 & 15 \\
\hline & $0.3378^{*}$ & $0.3616^{*}$ & $0.2139 *$ & $0.4343^{*}$ & $0.1246^{\mathrm{ns}}$ \\
\hline & 16 & 17 & 18 & 19 & 20 \\
\hline EC & $0.2640^{*}$ & $0.2646^{*}$ & $0.2566^{*}$ & $0.4092 *$ & $0.3591^{*}$ \\
\hline
\end{tabular}

* Significant by $\mathrm{t}$-test at $5 \%$ level of error probability; $\mathrm{ns}=$ Not significant by $\mathrm{t}$ test.

The other methodologies (Standard. 1, 3, 4, $6,8,9,10,11,12,14,16,17,19$ and 20), presented in Table 5, when compared with the field emergency test, a significant positive correlation by the t-test at the level of $1 \%$ probability of error. Being able to highlight the methodological adaptations with higher correlation values, being them: methodology 4 with $r=0.4121$, this refers to the use of saline solution with pre-treatment in refrigerator at 5 $10{ }^{\circ} \mathrm{C}$ for 24 hours, after being sent to BOD regulated at $42{ }^{\circ} \mathrm{C}$ for 24 hours; methodology 14 with $r=0.4343$, pertaining to the use of saline solution with pre-treatment in an forced air oven at $35-40{ }^{\circ} \mathrm{C}$ for two hours, shortly after being sent to BOD with a temperature of $42{ }^{\circ} \mathrm{C}$ exposed for 24 hours; and methodology 19 with a value of $r=$ 0.4092 , being responsible for adapting the pretreatment in an forced air oven at $35-40{ }^{\circ} \mathrm{C}$ for two hours, sent to BOD regulated at $45^{\circ} \mathrm{C}$ for a period of 12 hours.

Due to the accelerated aging test being one of the most used for the evaluation of the vigor of the lots, it is important to make the test more 
agile to corroborate the decisions taken by the producer aiming at his crop with greater productivity. Thus, attention is drawn to the two methodologies 14, 19 and 4, as they are the ones that achieved relevant results and present a shorter test period.

Having a greater emphasis on methodology 19 , which showed positive results in just 14 total hours of testing, in addition to enabling quick results, it also decreased the cost of the test, not in terms of material, but mainly in terms of time, using less electricity from the equipment and having a greater optimization of laboratory activities of quality control. These common justifications also serve for methodologies 14 and 4 however they had a test period of 26 and 48 hours, respectively.

\section{Conclusions}

Methodologies 14 (pre-treatment in a forced air oven at $35-40{ }^{\circ} \mathrm{C}$ for two hours, BOD $42^{\circ} \mathrm{C}$ for 24 hours, using saline) and 19 (pretreatment in a forced air oven at $35-40^{\circ} \mathrm{C}$ for two hours, BOD $45^{\circ} \mathrm{C}$ for 12 hours, with the use of distilled water) are the most suitable for use in the accelerated aging test for soybean crops, as they present relevant results in a shorter evaluation period.

\section{Acknowledgments}

To the Coordenação de Aperfeiçoamento de Pessoal de Nível Superior (Capes)-Financing code 001-and the Federal Pelotas University (UFPEL) for the technical support to this research's development.

\section{References}

AGUERO, J. A. P.; VIEIRA, R. D.; BITTENCOURT, S. R. M. Avaliação da qualidade fisiológica de sementes de cultivares de soja. Revista Brasileira de Sementes. v. 19, n. 2, p. 225-60, 1997.

https://doi.org/10.17801/0101-

3122/rbs.v19n2p254-259

BINOTTI, F. F. S.; HAGA, K. I.; CARDOSO, E. D.; ALVES, C. Z.; SÁ, M. E. E; ARF, O. Efeito do período de envelhecimento acelerado no teste de condutividade elétrica e na qualidade fisiológica de sementes de feijão. Acta Scientiarum Agronomy. v. 30, n. 2, p. 247-254, 2008. https://doi.org/10.4025/actasciagron.v30i2.1736

BRASIL. Ministério da Agricultura. Pecuária e Abastecimento. Regras para análise de sementes. Brasília: MAPA/ACS, 2009. 399 p.

BRAZ, M. R. S.; ROSSETTO. C. A. V. Correlação entre testes para avaliação da qualidade de sementes de girassol e emergência das plântulas em campo. Revista Ciência Rural, v. 39. n. 7. p. 2004-2009, 2009. https://doi.org/10.1590/S0103$\underline{84782009005000146}$

COSTA, C. J.; VILLELA, F. A.; BERTONCELLO, M. R.; TILLMANN, M. A. A.; MENEZES, N. L. Préhidratação de sementes de ervilha e sua interferência na avaliação do potencial fisiológico. Revista Brasileira de Sementes, v. 30, n. 1, p. 198-207, 2008.

https://doi.org/10.1590/S0101$\underline{31222008000100025}$

EGLI, D. B.; RUCKER, M. Seed vigor and the uniformity of emergence of corn seedling. Crop Science. v. 52, n. 6, p. 2774-2782, 2012. https://doi.org/10.2135/cropsci2012.01.0064

HENNING, F. A.; MERTZ, L. M.; JACOB JUNIOR, E. A. Composição química e mobilização de reservas em sementes de soja de alto e baixo vigor. Revista Bragantia, v. 69, n. 3, p. 727-734, $2010 . \quad \quad$ https://doi.org/10.1590/S0006$\underline{87052010000300026}$

JIANHUA, Z.; McDONALD, M. B. The saturated salt accelerated aging test for small seeded crops. Seed Science and Technology, v. 25, p. 123-131, 1996.

MARCOS FILHO, J. Testes de vigor: importância e utilização. In: KRZYZANOWSKI, F. C.; VIEIRA, R. D.; FRANÇA NETO, J. de B. (Ed.). Vigor de sementes: conceitos e testes. Londrina: Associação Brasileira de Tecnologia de Sementes, 1999. cap. 1. p. 1-20.

MARCOS FILHO, J. Fisiologia de sementes de plantas cultivadas. Londrina: ABRATES, 2015. $659 \mathrm{p}$.

MATERA. T. C.; PEREIRA. L. C.; BRACCINI. A. L.; KRZYZANOWSKI. F. C.; SCAPIM. C. A.; PIANA. S. C.; MARTELI. D. C. V.; PEREIRA. R. C.; FERRI. G. C.; SUZUKAWA. A. K. Accelerated aging test and its relationship to physiological potential of soybean seeds. Journal of Seed Science, v. 41, n. 3, p. 301-308, 2019.

https://doi.org/10.1590/2317- 
SANTOS, A. S.; SOUZA, E. M.; FÉBOLI, A.; NOGUEIRA, D. C. Testes de vigor em sementes de três cultivares de soja. Revista Conexão Eletrônica, v. 14, n. 1, p. 674-685, 2017.

SCHOSSLER, T. R.; MACHADO, M. M.; ZUFFO, A. M.; ANDRADE, F. R.; PIAUILINO, A. C. Salinidade: efeitos na fisiologia e na nutrição mineral de plantas. Enciclopédia Biosfera, v. 8., n. 15, p. 1563, 2012.

TUNES, L. M.; PEDROSO, D. A.; BARBIERI, A. P. P.; CONCEIÇÃO, G. N.; ROETHING, E.; MUNIZ, M. F. B.; BARROS, A. C. S. A. Envelhecimento acelerado modificado para sementes de coentro (Coriandrum sativum L.) e sua correlação com outros testes de vigor. Revista Brasileira de Biociência, v. 9, n. 1, p. 12-17, 2011.

TUNES, L. M.; TAVARES, L. C.; BARROS, A. C. S. A. Envelhecimento acelerado como teste de vigor para sementes de arroz. Revista de Ciências Agrárias, v. 35, n. 1, p. 120-127, 2012.

VANZOLINI, S.; CARVALHO, N. M. Efeito do vigor de sementes de soja sobre o seu desempenho em campo. Revista Brasileira de Sementes, v. 24, n. 1, p. 33-41, 2002. https://doi.org/10.1590/S0101$\underline{31222002000100006}$ 